\title{
A Research on the Relationship between the Development of Renewable Energy and Low-carbon Economy in China*
}

\author{
Yaning Zhang \\ Northeast Electric Power University \\ Jilin, PR China 132012
}

\author{
Ruiting Fan \\ Northeast Electric Power University \\ Jilin, PR China 132012
}

\author{
Changlin $\mathrm{Ji}^{* *}$ \\ Northeast Electric Power University \\ Jilin, PR China 132012 \\ **Corresponding Author
}

\begin{abstract}
Based on the connotation of renewable energy, low-carbon economy and its vision of future development, this study analyzes the relationship between renewable energy and low-carbon economy, social complementarity and coordinated development. It is proposed that renewable energy is an important foundation and effective guarantee for the development of low-carbon economy. The development of lowcarbon economy, which is the driving force behind the development of renewable energy, also put forward measures to promote the construction of low-carbon economy.
\end{abstract}

Keywords—renewable energy sources; low-carbon economy

\section{INTRODUCTION}

The development of a low-carbon economy as the basic way to coordinate the social and economic development, ensure energy security and combat climate change has reached the consensus of all countries in the world. Renewable energy has become a global energy transformation to protect the climate as the prerequisite for further major strategic initiatives to promote economic development. The basic trend of global energy transformation is to achieve the transformation of fossil energy system to low-carbon energy system, and ultimately to achieve a renewable energy-based economic development model.

Throughout the history of China's economic development in the past decade or so, the rapid development of urbanization and industrialization has promoted the largescale consumption of fossil fuels and caused serious problems of China's carbon dioxide emissions. For example, Chinese economy has kept an average annual growth rate of

*The paper is the initial results of Soft science project of Jilin provincial science and Technology Department, Research on the realization mechanism and path of Jilin electricity consumption side reform under the dual goal (20180418134FG), Jilin Social Science Fund Project, Research on the influence factors and low carbon development of Jilin's energy consumption structure change(2017BS19). about $10 \%$ since the year 1978. The average annual growth rates of the primary energy consumption and electricity consumption were $6 \%$ and $9.2 \%$ [1], respectively. Notably, the growth rate of fossil-fuel $\mathrm{CO} 2$ emissions was consistent with the growth rate of the primary energy consumption [2].It can be seen that China's economic growth is largely determined by primary energy.

At present, China is the second largest producer and consumer of energy in the world and the second largest one in terms of carbon dioxide Emissions countries as well. As being in the middle stage of industrialization in particular, with the obvious characteristics of the heavy chemical industry, China relies too much on single energy sources, with coal up to $70 \%$. So much so that China will inevitably consume a large amount of resources and energy for a long period of time. According to a report released by the International Energy Agency, it is estimated that by 2010, China will likely overtake the United States to become the world's largest emitter of greenhouse gases.

\section{OVERVIEW OF RENEWABLE ENERGY AND LOW- CARBON SOCIETY}

\section{A. The Connotation of Renewable Energy and Low-carbon Society}

Renewable energy refers to a variety of limitless reserve of energy, including wind, solar, biomass, hydropower, geothermal energy and ocean energy, and so on, with its superiority of wide distribution, utilization of resources, less environmental pollution and sustainability, etc. It is an important energy that is beneficial to the harmonious development between man and nature. From a strategic perspective, the development of environmentally friendly renewable energy has become an inevitable choice for China's sustainable energy strategy. 
Low-carbon economy is an economic model based on low energy consumption, low pollution and low emission. It is another major step forward for ecological civilization of human society after agricultural civilization and industrial civilization. Low-carbon economy is a new mode of economic development, likewise a new concept of enterprise development. The traditional economic growth pattern in China is characterized by high input - high consumption high pollution - high emission - low efficiency, extensive economic growth of which has contributed to high energy consumption and high carbon emissions. The concept of low-carbon economy provides new ideas for energy conservation and emission reduction. Transforming the economic growth pattern and promoting economic structural adjustment is the core task of developing low-carbon economy [3].

\section{B. The Significance of Developing Renewable Energy for Low-carbon Activities}

China's renewable energy resources are abundant which can meet the needs of development and utilization. Among them: water energy resources technology can develop installed capacity of 540 million $\mathrm{kW}$, annual power generation 2.47 trillion $\mathrm{kWh}$; Biomass resources can be converted into energy with a potential of 1 trillion $\mathrm{kg}$ of standard coal. Wind energy resources can be developed in total about 1 billion $\mathrm{kW}$; the available geothermal resources are about 3.3 trillion $\mathrm{kg}$ of standard coal [4]. In China's 9.6 million $\mathrm{km} 2$ land, the total amount of solar energy received annually reaches 1,700 trillion $\mathrm{kg}(50000 \mathrm{EJ})$, which is equal to 280 times the total annual energy consumption in 2050 [5]. In addition, China also has abundant geothermal energy and ocean energy. Thus, renewable energy is fully equipped as a substitute for traditional energy.

The development of renewable energy sources is the largest and most direct contribution to the low-carbon, clean and carbon-reducing greenhouse gases of China's energy structure. Methane, for example, the household biogas digester was 35 million, 2009, a year can save coal of 320 million $\mathrm{kg}$, carbon dioxide 31.36 billion $\mathrm{kg}$, sulfur dioxide emissions in 588 million $\mathrm{kg}$. In the straw, for example, the straw is a good renewable energy. The average sulfur content of straw is $0.38 \%$, while the average sulfur content of coal is $1 \%$. China is rich in biomass resources. It is reported that currently only waste crop straw is about 100 billion $\mathrm{kg}$, equivalent to 50 billion $\mathrm{kg}$ of standard coal. Biomass power generation will be China's largest environmental protection project. If China's biomass energy consumption reaches 500 billion $\mathrm{kg}$ of standard coal, it can solve the current energy consumption of more than 20 percent in China. At least 350 billion $\mathrm{kg}$ of carbon dioxide is emitted each year. It also reduced emissions of sulfur dioxide, nitrogen oxides and soot by nearly 25 billion kilograms [6].

\section{THE CONTRIBUTION OF RENEWABLE ENERGY TO REDUCING CARBON EMISSIONS}

\section{A. Proportion of Fossil Energy Consumption Remains High}

In recent years, China's tertiary industry and other terminal energy consumption have increased rapidly, but industrial terminal energy consumption still accounts for a high proportion of overall terminal energy consumption. In 2016, China's total energy consumption totaled 3.23 billion tons of standard coal, accounting for $61 \%$ of the industrial sector, $21 \%$ for the transportation sector and $14 \%$ for the construction sector.

Throughout the years of China's total energy production, from 2010 to 2016, China's overall energy production has been steadily rising. In 2016, China's energy consumption totaled 4.36 billion tons. Coal accounts for 62 percent of total consumption, and coal consumption is down 4.7 percent from 2015, oil is 18.3 percent, natural gas is 6.4 percent, and electricity and other energy sources are 13.3 percent. Despite the huge growth in renewable energy in China over the past decade, the current energy system is still far away from clean, efficient, safe and sustainable development goals.

the proportion of terminal energy consumption in China's various industries in 2016

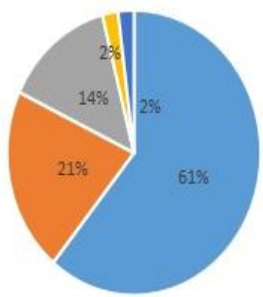

- industrial engineering = transportation = construction $=$ agriculture | architecture

Fig. 1. The proportion of terminal energy consumption in China's various industries in 2016

The proportion of China's energy resources in 2016.

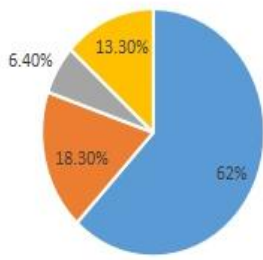

W coal = oil = Natural gas $=$ Primary electricity and other energy sources.

Fig. 2. The proportion of China's energy resources in 2016.

\section{B. The Benefits of New Energy Emission Reduction Are Obvious}

During the 12th five-year plan period, China's renewable energy industry began to scale up in an all-round way, and entered a stage of development of large-scale incremental substitution and regional stock replacement. 
First, the role of renewable energy in promoting the adjustment of energy structure has been enhanced. In 2015, China's commercial renewable energy consumption was 436 million tons of standard coal, accounting for $10.1 \%$ of the total energy consumption. If solar thermal utilization and other non-commercial renewable energy are taken into account, the annual consumption of renewable energy will reach 500 million tons of standard coal. By the end of 2015, the country's hydropower capacity is 320 million kilowatts. The installation of wind power and photovoltaic power grid is 129 million $\mathrm{kW}$ and $4318 \mathrm{mw}$ respectively. The solar thermal utilization area is over 400 million square meters, and the application scale is the first in the world. The total amount of renewable energy is 1.38 trillion kilowatt-hours, which accounts for about $25 \%$ of the total electricity consumption of the whole society, of which $5 \%$ is non-water renewable energy. Biomass can continue to diversify, and biomass energy consumption is about 35 million tons of standard coal, of which the commercial biomass is about 18 million tons of standard coal annually as to 2015 .

\section{The Policy System for Renewable Energy Development Is Gradually Improving}

Since 2007, China's new energy generation industry has achieved remarkable results. According to the data, the total installed capacity of nuclear power, wind power and photovoltaic has reached 33.64 million $\mathrm{kW}, 169$ million $\mathrm{kW}$, and 77.42 million kilowatts respectively. The total power generation of these three is 212.7 billion kilowatt hours, 211.3 billion kilowatt hours and 66.2 billion kilowatt-hours, with total generating capacity of 490.2 billion kilowatt-hours.

TABLE I. RENEWABLE ENERGY DEVELOPMENT

\begin{tabular}{|l|l|l|l|l|}
\hline & $\begin{array}{l}\text { New energy generation } \\
\text { (billion hours) }\end{array}$ & $\begin{array}{l}\text { National annual carbon } \\
\text { emission (billion tons) }\end{array}$ & $\begin{array}{l}\text { New engy years reduce } \\
\text { emissions. (billion tons) }\end{array}$ & Reduction ratio \\
\hline 2012 & 2027 & 10.02 & 0.17191 & $1.72 \%$ \\
\hline 2013 & 2548 & 10.25 & 0.22657 & $2.21 \%$ \\
\hline 2014 & 3101 & 10.284 & 0.27641 & $2.69 \%$ \\
\hline 2016 & 3972 & 10.15 & 0.35395 & $3.49 \%$ \\
\hline
\end{tabular}

Nuclear, wind and light generate electricity equal to $12.48 \%$ of coal. In 2016, coal consumed about 1.8 billion tons, which in turn accounted for about 225 million tons standard coal. At 2015 about 100,5 kilowatt-hours of electricity coal consumption to calculate, the new energy

power generation to reduce carbon dioxide emissions quantity reached 436 million tons, basically the equivalent of coal energy saving reform achievements. The chart below shows the development of new energy sources.

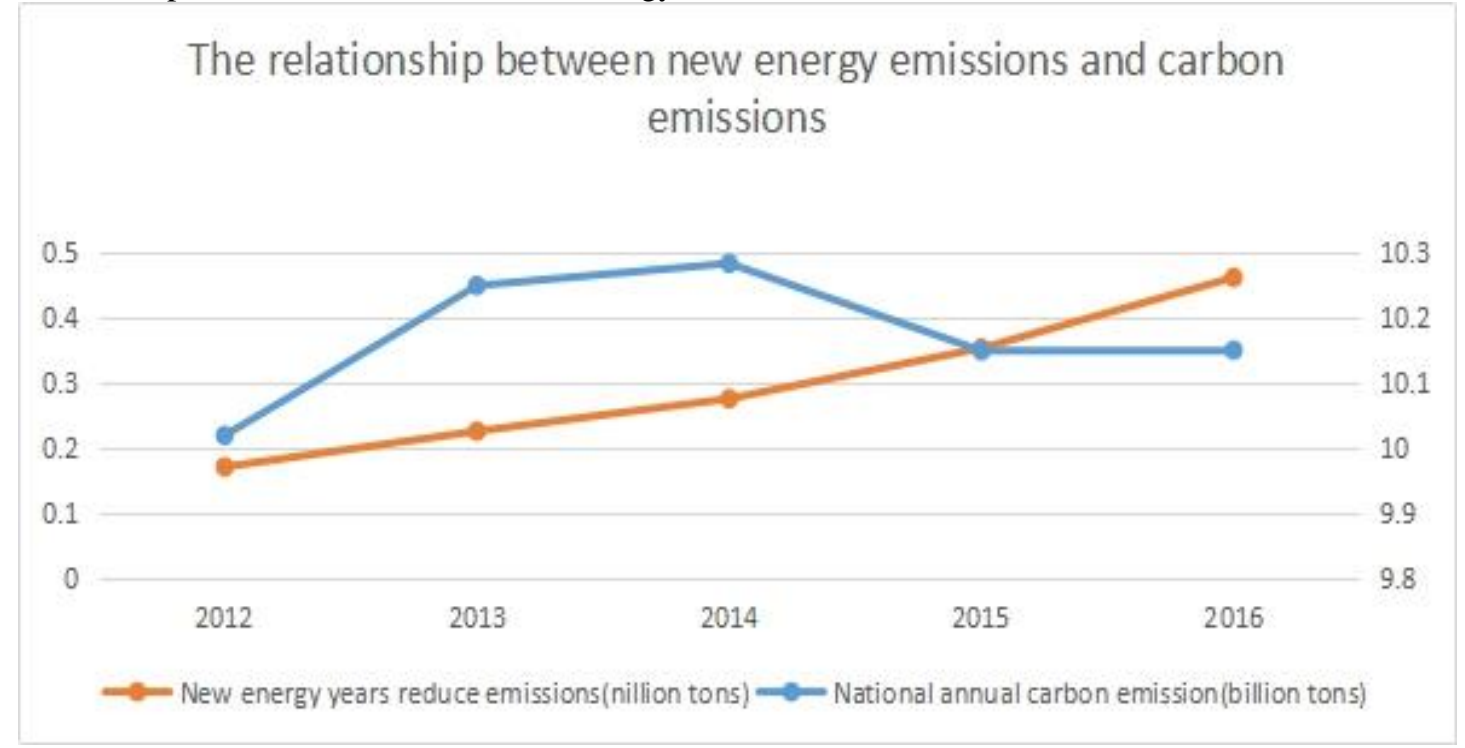

Fig. 3. The development of new energy sources.

More importantly, according to the national energy administration's 13th five-year plan, coal power is expected to be limited to 1.1 billion kilowatt-hours by 2020 . The installed capacity of wind power, nuclear power and photovoltaic will reach 210 million, 0.58 billion and 250 million kilowatts respectively, and the carbon emission reduction benefits of new energy will be further strengthened.

\section{The PRoblems We Face Today}

With the progress of renewable energy technology and the acceleration of industrialization, China's renewable energy has already had the industrial base of large-scale development and application. Although it shows good prospects for development, it is also faced with obvious 
constraints on institutional mechanism, mainly in the following aspects:

The existing power operation mechanism is not suitable for the development of renewable energy scale. The power system with traditional energy is not enough to meet the requirements of the grid operation of wind power and photovoltaic power generation. Power market mechanism and price mechanism are not perfect. The power system's flexibility has not been fully developed. The technical management system for the coordinated development of renewable energy and other power sources has not yet been established. There are still technical barriers to the largescale grid connection of renewable energy.

Renewable energy is not being used effectively. Although renewable energy installations, especially new energy generation, are growing rapidly year by year, the responsibilities and obligations of market entities in renewable energy use are unclear. The utilization rate is not high. Supply and demand are unbalanced and uncoordinated. The potential for sustainable development of renewable energy has not been fully tapped. The proportion of renewable energy in primary energy consumption is still lower than that of advanced countries.

\section{CONCLUSION}

\section{A. Measures Taken by the Government}

Renewable energy already has unprecedented development opportunities. The government must attach great importance to the development of renewable energy. Strengthen policy guidance and expand investment channels. We need to develop technologies that are conducive to the development of renewable energy. We will reduce the cost of renewable energy development and expand the scale of development through subsidies, subsidies, taxation and land incentives. We should increase fiscal input and effective tax and price policies to support renewable energy development.

The combination of low-carbon economy and economic development mode has transformation. In order to adapt to modern economic structure change, our country need to make a series of adaptive adjustment of the pattern of economic development: from the extensive, as inputs to the essential characteristics of traditional growth mode, to intensive, increasing the service efficiency of elements as the essential characteristics of modern growth pattern change; From the high consumption of traditional industrialization mode to the low consumption of modern industrial model.

\section{B. Suggestions on the Development of Low-carbon Economy in Chinese Enterprises}

It is necessary to establish a low carbon consciousness enterprise, and to realize that the low-carbon economy is a new growth point of economy. As an industrial revolution, low-carbon economy will help economic development. Second, we should fully recognize the urgency of developing a low-carbon economy. If we establish a low-carbon concept, the development of low-carbon economy as a top priority will bring huge business opportunities and benefits to enterprises.

On the other hand, enterprises should increase research and development, increase investment in low-carbon technologies, and improve their ability to innovate in lowcarbon technologies. If enterprises can seek technological breakthroughs in green consumption technology and ecological recovery technology, they will increase resource productivity and energy efficiency more. At the same time, it should also selectively introduce, absorb and re-innovate the forms of foreign advanced low-carbon technologies. Enterprises should continuously improve the innovation ability of enterprises' low carbon technology, thus improving the core competitiveness of enterprises.

\section{REFERENCES}

[1] Diebold F. X. and K. Yilmaz. Better to Give than to Receive: Predictive Directional Measurement of Volatility Spillovers. International Journal of Forecasting,2012,28(1):57-66.

[2] Kim J, Park K. Financial development and deployment of renewable energy technologies. Energy Economics. 2016,59(9):238-250.

[3] Fukunari K, Shigeru K, Youngho C, et al. Financing renewable energy in the developing countries of the East Asia Summit region: Introduction. Energy Policy. 2016,95(8):421-426.

[4] Sopitsuda T, Sunee M, Apinya A, et al. Business models and financing options for a rapid scale-up of rooftop solar power systems in Thailand. Energy Policy. 2016,95(8):447-457.

[5] Gireesh S, David N, Shobhit G, et al. Renewable deployment in India: Financing costs and implications for policy. Energy Policy. 2013,62(11):28-43

[6] Nadia A, Daniel M. Innovations in financing that drive cost parity fo long-term electricity sustainability: An assessment of Italy, Europe's fastest growing solar photovoltaic market. Energy for Sustainable Development. 2014,19(4):130-137. 